\title{
Testing the Costumers' Purchase Intention of an Artificial Sweetener Product: Do Brand Image Have an Effect?
}

\author{
Usep Suhud ${ }^{1}$ and Surianto ${ }^{2}$ \\ ${ }^{1}$ Faculty of Economics, Universitas Negeri Jakarta, Jakarta, Indonesia \\ ${ }^{2}$ London School of Public Relations, Jakarta, Indonesia
}

Correspondence should be addressed to: Usep Suhud; usuhud@unj.ac.id

Received date: 4 January 2018; Accepted date: 27 June 2018; Published date: 08 October 2018

Academic Editor: Muhammad Sufyan

Copyright (C) 2018. Usep Suhud and Surianto . Distributed under Creative Commons CC-BY 4.0

\begin{abstract}
Indonesia is one of the countries with the highest number of diabetics in the world and diabetic in this archipelago became one of the deadliest diseases. Creating awareness about the dangers of diabetic could be an opportunity for producers of a sweetener product while offering a solution that is expected to establish the company's reputation. This study aims to examine the influence of corporate reputation and brand image on brand loyalty. A survey was conducted in modern markets in Jakarta and collected 250 useable data. Participants were selected purposively; those who bought more than once a specific sweetener product. Data were analysed using exploratory and structural equation model. This study found a significant effect of corporate reputation on brand image and brand loyalty, as well as brand loyalty on a purchase intention. This study discusses recommendations for practitioners and future research.
\end{abstract}

Keywords: Corporate reputation, brand image, brand loyalty, purchase intention, artificial sweetener product, structural equation model

\section{Introduction}

Indonesia has been ranked fifth as the country with the highest number of diabetics in the world and third in Asia (Susilawati \& Rezkisari, 2015) and diabetic is a type of fourth-most deadly disease in this archipelago country
(Widowati, 2015). By seeing these facts, producers of low-sugar or sugar-free products should have an excellent opportunity to educate public about the dangers of excessive sugar consumption and its impact on health, while offering their products.

Cite this Article as: Usep Suhud and Surianto (2018), " Testing the Costumers' Purchase Intention of an Artificial Sweetener Product: Do Brand Image Have an Effect? “ Journal of Marketing Research and Case Studies, Vol. 2018 (2018), Article ID 557730, DOI: 10.5171/2018.557730 
When sugar is considered unhealthy to be consumed (Patel et al., 2017), a substitute product has been offered to consumers. There are two potential target markets to purchase and consume a sweetener product including those who live with diabetics and those who practise healthy life. Researchers (for example, Hoffmann \& Greene, 2017; Lin, Wu, Oturan, Zhang, \& Oturan, 2016) in the fields of health, chemistry, and pharmacy have researched with artificial sweeteners as an object. However, in the marketing field of study, consumer behaviour relating to a sweetener product has a lack of scholarly attention. Therefore, this study aims to examine the influence of corporate reputation, brand image, and brand loyalty on purchase intention.

This current study measured the purchase intention of participants who are customers of an artificial sweetener. One of the predictors is brand loyalty. As involving brand loyalty, the participant should be a loyalist of the object of this study. According to Jacoby and Kyner (1973), being loyal is different with repeating purchasing. Brand loyalty is "(1) the biased (i.e. non-random), (2) behavioural response (i.e. purchase), (3) expressed over time, (4) by some decision-making unit, (5) with respect to one or more alternative brands out of asset of such brands, and (6) is a function of psychological (decision-making, evaluative) process" (Jacoby \& Kyner, 1973, p. 2). Further, they continued, "loyalty would be manifested only by those subjects who had made prior selections under conditions where (1) more than one brand had been available in the product category, and (2) choice had been expressed behaviourally rather than by merely stating an intent to purchase" (Jacoby \& Kyner, 1973, p. 3). Brand loyalty becomes essential to learn because, from many studies (Alhaddad, 2014; Shukla, 2009), it says that brand loyalty can impact brand equity and purchasing intentions.

The authors also choose corporate reputation and brand image as predictors.

\section{Literature Review}

\subsection{Theoretical background}

\subsubsection{Corporate reputation, brand image, and brand loyalty}

Corporate reputation is "perceptions of how the firm behaves towards its stakeholders and the degree of informative transparency with which the firm develops relations with them" (de la Fuente \& de Quevedo, 2003, p. 280). According to Schwaiger (2004), there are ten components of corporate reputation, including quality of employees, quality of the management, financial performance, quality of products and services, market leadership, customer orientation or focus, attractiveness or emotional appeal of the organisation, social responsibility, ethical behaviour, and reliability. Fombrun, Ponzi, and Newburry (2015) developed dimensions of corporate reputation. They included products, innovation, workplace, governance, citizenship, leadership, and performance. Further, Dijkmans, Kerkhof, and Beukeboom (2015) outlined dimensions of corporate reputation as emotional appeal, products and services, vision and leadership, workplace environment, social and environmental responsibility, and financial performance.

There are factors influencing corporate reputation. Ali, Lynch, Melewar, and Jin (2015) mentioned firm size, media visibility, corporate social performance, firm risk, firm age, and longterm institutional ownership. Further, corporate reputation is assessed to change customer loyalty, financial performance, customer trust, and customer commitment (Ali et al., 2015).

Corporate reputation is a crucial factor to influence others, such as market value, organisation's performance, and business performance. It also can affect customer satisfaction, service quality, perceived value, corporate social responsibility, competitiveness, public relations, and customer loyalty (Awang \& Jusoff, 2009; Cecilia, 2014; Cole, 2012; Cretu \& Brodie, 2007; Gorondutse, Hilman, \& Nasidi, 2014; Johan \& Noor, 2013; Piriyakul \& Wingwon, 2013).

Liengjindathaworn, Saenchaiyathon, and Hawat (2015) mentioned that corporate reputation could influence the brand image. On the other way, corporate reputation can be affected by CSR, corporate brand responsibility, and customer satisfaction (Hsu, 2012; Hur, Kim, \& Woo, 2014). Further, in the study of Seo and Park (2016), corporate reputation was linked to a brand image, price, perceived service quality, and brand preference. This study was addressed to examine Korean customer loyalty in the airline business. This study found a significant effect of corporate reputation on brand image.

A study undertaken by Cretu and Brodie (2007) employed brand image, corporate reputation, 
and customer value to assess customer loyalty of three manufacturers who produced FMCG product, particularly, shampoo for professionals. This study involved salon managers in $\mathrm{New}$ Zealand. They found a significant impact on corporate reputation on customer loyalty. Further, Almeida, da Graça, and Coelho (2005) focussed on the loyalty of members of three different cooperatives in Portugal. They selected predictor variables including communication, corporate reputation, and image. They found that corporate reputation significantly influenced image and loyalty.

Here are two hypotheses based on the literature discussed above:

$H_{1}$ - Corporate reputation will have a significant effect on brand image

H2 - Corporate reputation will have a significant effect on brand loyalty

\subsubsection{Brand Image and Brand Loyalty}

A brand is essential for a product. Aaker (2009) stated that a brand should reach an equity by considering its four dimensions including brand awareness, perceived quality, brand association, brand loyalty, and other brand assets. Bivainienè and Šliburytè (2008) added another dimension of brand equity that is brand image. According to Saleem and Raja (2014), service quality, customer satisfaction, and customer loyalty can shape a brand image.

Prior studies used a brand image as a good predictor for product and service quality, brand equity, purchase decision, and brand loyalty (Alhaddad, 2014; Ambolau, 2015; Cretu \& Brodie, 2007) while Saleem and Raja (2014) connected brand loyalty to brand image, in this current study, brand image is related to brand loyalty.

In the study of Seo and Park (2016), there were two variables of loyalty including behavioural loyalty and attitudinal loyalty. In this study, brand image was linked to these two loyalty variables. They found that brand image had a significant influence on behavioural loyalty whereas it was found to have an insignificant impact on attitudinal loyalty. Even Zhang, Fu, Cai, and Lu (2014), in a tourism setting, included three different loyalty including behavioural loyalty, attitudinal loyalty, and composite loyalty. Destination image influenced these three variables. Bandyopadhyay and Martell (2007) said that attitudinal loyalty could influence behavioural loyalty.
A different result was shown by Alwi and Kitchen (2014). They tested the loyalty of students towards a business school, private or public; they were registered to. In their theoretical framework, they included cognitive brand attribute, effective brand attribute, corporate brand image, and satisfaction. These authors involved university students in Malaysia. One of the findings they carried out was that there was an insignificant impact of the corporate brand image on loyalty.

A hypothesis is formulated based on the studies discussed above:

$\mathrm{H}_{3}$ - Brand image will have a significant effect on brand loyalty

\subsubsection{Brand Loyalty and Purchase Intention}

Momani (2015) differentiates consumers based on their loyalty level. First is hardcore loyalty. This loyalty is intended for consumers who have high loyalty for choosing a particular brand continuously. The second is split loyalty; designed for consumers who have more than one brand choice, then alternately select one among the brands. Then, there is shifting loyalty. This kind of loyalty is addressed to consumers who switch to other brands. Fourth is the switcher. This type of loyalty represents consumers who are continually changing brands without showing commitment to any one brand. Prior studies (Alhaddad, 2014; Espejel, Fandos, \& Flavian, 2008; Shukla, 2009) applied brand loyalty to examine brand equity, purchase intention, and purchase decision. In this current research, brand loyalty is linked to purchase intention.

Taking place in Spain, Espejel et al. (2008) studied the purchase intention of olive oil consumers. They employed satisfaction and loyalty as predictors. They demonstrated a significant effect of loyalty on purchase intention. Further, Das (2014) paid attention on Indian retailers' purchase intention. According to this scholar, retailer loyalty could be influenced by retailer awareness, retailer association, and retailer perceived quality. One of the findings he carried out was a significant impact of retailer loyalty on purchase intention.

Another study was conducted by Khan, Rahmani, Hoe, and Chen (2014). In that study, brand loyalty was affected by brand image, brand awareness, and perceived quality. Further, brand loyalty was connected to purchase intention. They found that brand 
loyalty had a significant influence on purchase intention.

Considering the above studies, therefore, the following hypothesis will be tested:

$\mathrm{H}_{4}$ - Brand loyalty will have a significant effect on purchase intention

\subsection{Theoretical Framework}

This current study is addressed to measure the interlinks among corporate reputation, brand image, brand loyalty, and purchase intention. Figure 1 indicates that corporate reputation is related to brand image and brand loyalty. Further, brand image is linked to brand loyalty, and brand loyalty is connected to purchase intention.

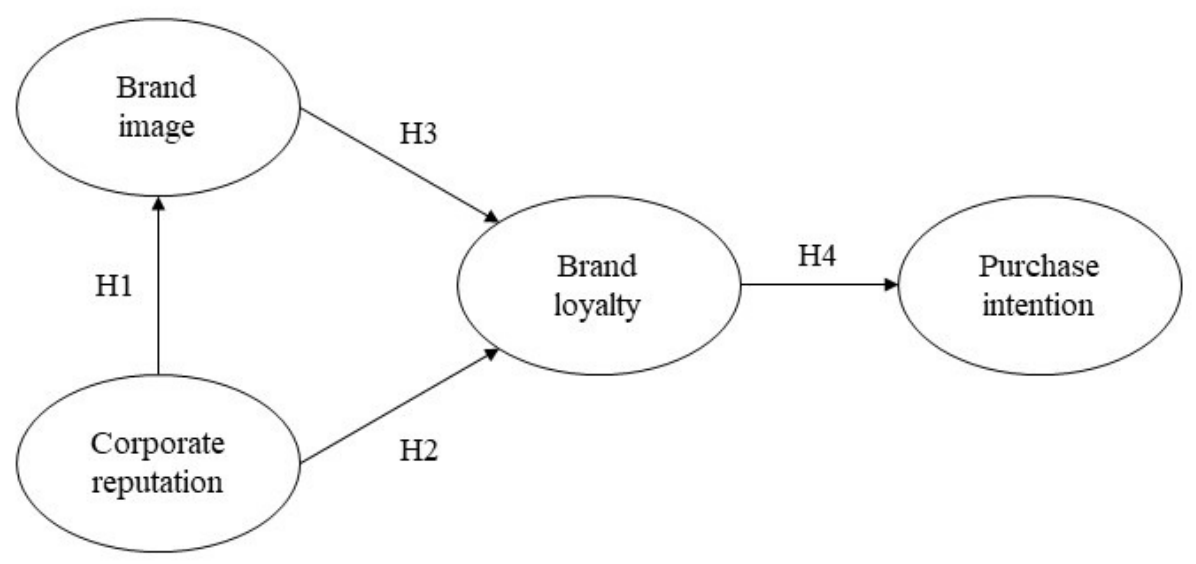

Figure 1: The proposed research model

\section{Research Methods}

\subsection{Sample}

The authors recruited participants in some minimarkets where the sweetener product was sold, in Jakarta. They were purposively approached and asked to be involved in filling in a selfadministered questionnaire. Participants were ensured to be a consumer of an artificial sweetener product that has purchased the product more than twice. In Indonesia, there are two brands of artificial sweetener products that compete, namely; Tropicana Slim and Diabetasol. This study focused on the consumers of Tropicana Slim.

\section{$2.2 \quad$ Measures}

The authors selected indicators taken from previous studies to measure variables included in this current study. Indicators from Pratoom (2010) were adapted to measure corporate reputation. Indicators to assess brand image were adapted from Prabowo (2013). Further, to test, brand loyalty the indicators were taken and adapted from Petzer, Mostert, Kruger, and Kuhn (2014).

\subsection{Data analysis}

To process the quantitative data that has been collected, the author performs three steps. The first step: the exploratory factor analysis (EFA) is to build the dimensions or constructs of each variable and ensure the most valid indicators of each construct. The second step calculated the reliability test of each variable and construct. The third step is to test the structural equation model (SEM). This test is intended to test the theoretical framework and hypotheses previously built. SEM test results can be seen if the model tested is fit. A fit model should have a probability score of $\geq 0.05$ (Schermelleh-Engel, Moosbrugger, \& Müller, 2003) and CMIN/DF score of $\leq 2$ (Tabachnick \& Fidell, 2007). Also, it should have a CFI score of $\geq 0.97$ (Hu \& Bentler, 1995) and RMSEA score of $\leq 0.05$ (Hu \& Bentler, 1999). 


\section{$3 \quad$ Results and Discussion}

\subsection{Participants}

In total, there were 250 participants participated with 74 males (29.6\%) and 176 females (70.4\%). Concerning age, 106 participants (41.6\%) were between 25 and 34 years old. Furthermore, 85 participants (34.0\%) were between 35 and 44 years old. Followed by
34 participants (13.6\%) aged between 15 and 24 years old. The rest, 27 participants (10.8\%) aged between 45 and 54 years. Furthermore, 102 participants $(40.8 \%)$ had expenses of Rp4 million (USD296) to IDR6 million (USD445) per month, followed by 72 participants (28.8\%) with expenses ranging from IDR6 million to IDR8 million (USD593) per month.

Table 1: Profile of participants

\begin{tabular}{|c|c|c|c|}
\hline & & Frequency & Percent \\
\hline \multirow[t]{3}{*}{ Sex } & Male & 74 & 29.6 \\
\hline & Female & 176 & 70.4 \\
\hline & Total & 250 & 100.0 \\
\hline \multirow[t]{4}{*}{ Age } & 15-24 years & 34 & 13.6 \\
\hline & $25-34$ years & 104 & 41.6 \\
\hline & $35-44$ years & 85 & 34.0 \\
\hline & 45-54 years & 27 & 10.8 \\
\hline \multirow[t]{5}{*}{ Income } & $<\mathrm{Rp} 2,000,000$ & 13 & 5.2 \\
\hline & $\mathrm{Rp} 2,000,001-\mathrm{Rp} 4,000,000$ & 44 & 17.6 \\
\hline & Rp4,000,0001 - Rp6,000,000 & 102 & 40.8 \\
\hline & Rp6,000,001 - Rp8,000,000 & 72 & 28.8 \\
\hline & $>\operatorname{Rp} 8,000,000$ & 19 & 7.6 \\
\hline
\end{tabular}

\subsection{Exploratory Factor Analysis}

Table 2 presents the results of exploratory factor analysis (EFA) of four variables including corporate reputation, brand image, brand loyalty, and purchase intention. Corporate reputation formed three constructs. The first construct had five indicators with factor loadings ranging from 0.499 to 0.613 and a Cronbach's alpha score of 0.565 . The second construct contained five indicators. The construct owned factor loadings ranging from 0.454 to -0.755 and a Cronbach's alpha score of 0.699 . The last construct of corporate reputation consisted of five indicators and factor loadings ranging from -0.641 to 0.776 . It had a Cronbach's alpha score of 0.603 .

Further, brand image consisted of two constructs. The first construct contained four indicators, and it had factor loadings ranging from 0.552 to 0.670 . The construct possessed a Cronbach's alpha score of 0.502 . The second construct obtained four indicators with factor loadings ranging from 0.581 to 0.688 . This second construct had a Cronbach's alpha score of 0.482 .
Moreover, brand loyalty formed two constructs. The first construct survived four indicators with factor loadings ranging from 0.503 to 0.693 . The construct achieved a Cronbach's alpha score of 0.488. The second construct retained three indicators. It had factor loadings ranging from 0.566 to -0.825 and a Cronbach's alpha score of 0.521. The last, purchase intention kept three indicators with factor loadings ranging from 0.701 to 0.751 . It had a Cronbach's alpha score of 0.565 .

Ideally, as suggested by Hair Jr., Black, Babin, Anderson, and Tatham (2006), constructs with a score less than 0.6 should be dropped from further analysis. However, in this current study, only constructs with factor loadings less than 0.5 that was deleted. This approach has been done by Suhud (2014). He said that the dimensions that are not or less reliable can be useful also in the calculation of SEM to obtain a fit model. The deleted dimensions were corporate reputation (4), brand image (2), and brand loyalty (2). They had scores of 0.299 , 0.502 , and 0.521 respectively. 
Table 2 : EFA results

\begin{tabular}{|c|c|c|c|}
\hline & & $\begin{array}{c}\text { Factor } \\
\text { loadings }\end{array}$ & $\begin{array}{l}\text { Cronbach's } \\
\text { alpha }\end{array}$ \\
\hline 1 & Corporate reputation (1) & & 0.689 \\
\hline $\mathrm{C} 1$ & I'm feeling good with the manufacturer of XYZ & 0.757 & \\
\hline $\mathrm{C} 2$ & I admire the manufacturer of XYZ & 0.752 & \\
\hline $\mathrm{C} 3$ & I respect the manufacturer of XYZ & 0.677 & \\
\hline $\mathrm{C} 4$ & I believe the manufacturer of XYZ & 0.601 & \\
\hline 2 & Corporate reputation (2) & & 0.565 \\
\hline $\mathrm{C} 7$ & The manufacturer of XYZ offers high-quality products & 0.632 & \\
\hline C11 & The manufacturer of XYZ knows the market opportunities. & 0.621 & \\
\hline C17 & $\begin{array}{l}\text { The manufacturer of XYZ is a company that is environmentally } \\
\text { responsible }\end{array}$ & 0.558 & \\
\hline $\mathrm{C} 13$ & The manufacturer of XYZ is well managed & 0.546 & \\
\hline $\mathrm{C} 9$ & The manufacturer of XYZ has superior leadership & 0.537 & \\
\hline 3 & Corporate reputation (3) & & 0.554 \\
\hline C18 & $\begin{array}{l}\text { The manufacturer of XYZ maintains a high standard in treating } \\
\text { humans }\end{array}$ & 0.776 & \\
\hline $\mathrm{C} 14$ & The manufacturer of XYZ looks like a good company to work for. & 0.667 & \\
\hline $\mathrm{C} 10$ & The manufacturer of XYZ has a clear vision. & 0.562 & \\
\hline $\mathrm{C} 8$ & The manufacturer of XYZ offers products that are worth the price & 0.455 & \\
\hline 4 & Corporate reputation (4) & & 0.299 \\
\hline $\mathrm{C} 12$ & The manufacturer of XYZ takes advantage of market opportunities. & 0.782 & \\
\hline C15 & $\begin{array}{l}\text { The manufacturer of XYZ looks like a company that has good } \\
\text { employees }\end{array}$ & 0.624 & \\
\hline 5 & Brand image (1) & & 0.502 \\
\hline B6 & $\mathrm{XYZ}$ is easy to pronounce & 0.670 & \\
\hline B8 & $\mathrm{XYZ}$ is easily recognisable & 0.652 & \\
\hline B4 & XYZ has a differentiation between product with other product & 0.602 & \\
\hline $\mathrm{B} 2$ & XYZ product price match with quality & 0.552 & \\
\hline 6 & Band image (2) & & 0.482 \\
\hline $\mathrm{B} 1$ & XYZ is a market leader in similar products & 0.688 & \\
\hline B5 & XYZ has a different physical appearance & 0.614 & \\
\hline B3 & $\mathrm{XYZ}$ is known to be of good quality & 0.584 & \\
\hline B7 & $\mathrm{XYZ}$ is easy to remember & 0.581 & \\
\hline 7 & Brand loyalty (1) & & 0.488 \\
\hline L6 & XYZ is the only brand I would prefer to use & 0.693 & \\
\hline L4 & I think only XYZ, the only brand I need & 0.639 & \\
\hline $\mathrm{L} 2$ & I buy XYZ products whenever I can & 0.607 & \\
\hline L1 & I am faithful to the XYZ brand & 0.503 & \\
\hline 8 & Brand loyalty (2) & & 0.521 \\
\hline L5 & $\mathrm{XYZ}$ is the only brand I would prefer to buy & -0.825 & \\
\hline L7 & If XYZ is not available, I would be hard-pressed to use another brand & -0.715 & \\
\hline L3 & I buy XYZ products as much as I can. & -0.566 & \\
\hline 9 & Purchase intention & & 0.565 \\
\hline D1 & I intend to buy XYZ & 0.751 & \\
\hline D3 & $\begin{array}{l}\text { With all things in mind, I will continue to buy XYZ products for up to } \\
5 \text { years }\end{array}$ & 0.746 & \\
\hline D2 & I plan to buy XYZ & 0.701 & \\
\hline
\end{tabular}




\subsection{Hypotheses Testing}

Figure 2 is the structural model of the hypotheses testing. The model achieved a fitness with a probability score of $0.537, \mathrm{CMIN} / \mathrm{DF}$ score of 0.983 , CFI score of 1.000, and RMSEA score of 0.000 . In the model, corporate reputation sustained two dimensions whereas three other variables had no dimensions.

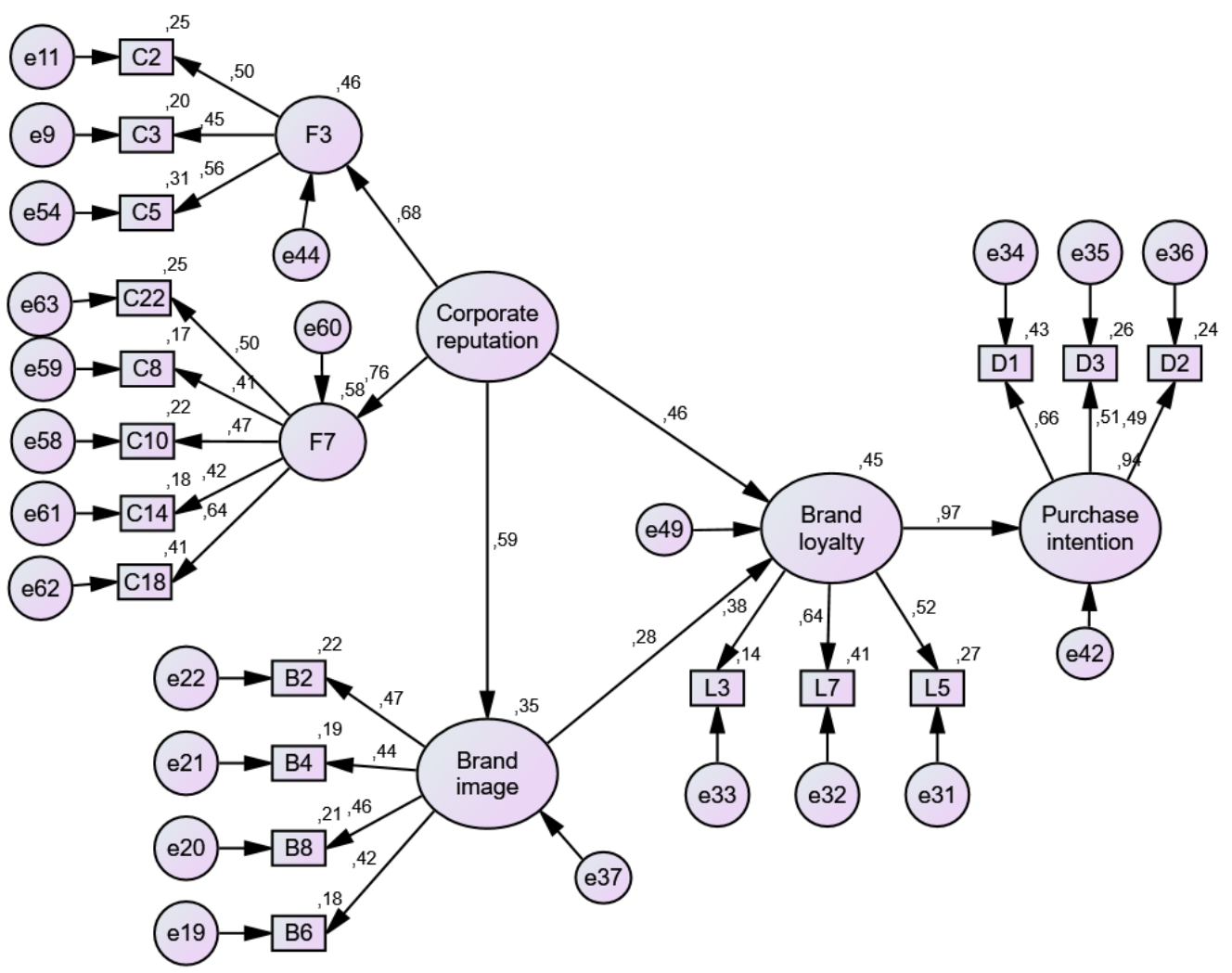

Figure 2 : The structural model of hypotheses testing

Table 4 shows the hypotheses testing results. In the table, three paths including $\mathrm{H}_{1}, \mathrm{H}_{2}$, and $\mathrm{H}_{4}$, had C.R. scores of 2.764, 2.106, and 4.683 respectively, whereas a path $\left(\mathrm{H}_{3}\right)$ had a score of 1.583. The first three C.R. scores show significances. Regarding the standardised total effects, $\mathrm{H}_{1}$ and $\mathrm{H}_{2}$ had scores of 0.588 and 0.630 respectively showing a strong effect. $\mathrm{H}_{3}$ owned a score of 0.234 indicating a weak effect and H4 had a score of 0.970 showing a very strong effect.

Table 3: Results of hypotheses testing

\begin{tabular}{|l|l|l|l|c|c|c|l|}
\hline & & & & C.R. & P & $\begin{array}{l}\text { Standardised } \\
\text { total effects }\end{array}$ & Interpretation \\
\hline $\mathrm{H}_{1}$ & $\begin{array}{l}\text { Corporate } \\
\text { reputation }\end{array}$ & $\rightarrow$ & Brand image & 2.764 & 0.006 & 0.588 & Strong effect \\
\hline $\mathrm{H}_{2}$ & $\begin{array}{l}\text { Corporate } \\
\text { reputation }\end{array}$ & $\rightarrow$ & Brand loyalty & 2.106 & 0.035 & 0.630 & Strong effect \\
\hline $\mathrm{H}_{3}$ & Brand image & $\rightarrow$ & Brand loyalty & 1.583 & 0.113 & 0.284 & Weak effect \\
\hline $\mathrm{H}_{4}$ & Brand loyalty & $\rightarrow$ & $\begin{array}{l}\text { Purchase } \\
\text { intention }\end{array}$ & 4.683 & $* * *$ & 0.970 & $\begin{array}{l}\text { Very strong } \\
\text { effect }\end{array}$ \\
\hline
\end{tabular}




\section{Discussion}

The first hypothesis predicted the impact of corporate reputation on brand image. The hypothesis was accepted. This finding is supported by prior studies (Almeida et al., 2005; Liengjindathaworn et al., 2015; Seo \& Park, 2016). In this case, the more positive the reputation of the artificial sweetener manufacturers, the more positive the image brand is. A positive brand image can form value creation, corporate communication, and strategic resources and these three aspects can then help companies build brand differentiation strategy (Vahabzadeh et al., 2017). Positive corporate reputation can also affect brand loyalty.

The second hypothesis predicted the impact of corporate reputation on brand loyalty. This hypothesis was accepted. This finding is supported by prior studies (Almeida et al., 2005; Cretu \& Brodie, 2007). Although the brand image is influenced by corporate reputation, it does not mean the company should focus on this one. In a study conducted by (Mohammad, 2017), brand image controlled brand experiences, brand equity, and corporate branding. That is many factors that can affect the brand image.

The third hypothesis predicted the impact of brand image on brand loyalty. This hypothesis was rejected. This finding contrasts with a result presented by prior studies (Seo \& Park, 2016; Zhang et al., 2014). However, it supports a survey undertaken by Alwi and Kitchen (2014) that shows an insignificant effect of brand image on brand loyalty. In another word, this study fails to show that brand image significantly affects brand loyalty. Consumer loyalty in this case, is only formed by corporate reputation. In fact, the company's reputation has been perceived to be stronger as a manufacturer of artificial sweetening products than the perception of the brand image of the synthetic sweetener product. In fact, the company has been using the brand not just for artificial sweeteners, but also for other products, such as fruit syrup and instant noodles.

The fourth hypothesis predicted the impact of brand loyalty on purchase intention. This hypothesis was accepted. In this case, consumers became a hardcore loyalist as well as a split loyalist (Momani, 2015) in term of their buying behaviour. These findings support findings of brought by the previous studies (Das, 2014; Espejel et al., 2008; Khan et al., 2014).

\section{Conclusion}

This study aimed to measure the impact of corporate reputation, brand image, and brand loyalty on purchase intention of an artificial sweetener product. Three of the four hypotheses examined were accepted. There was a significant effect of corporate reputation on brand image and brand loyalty, and a significant influence of brand loyalty on the purchase intention.

These findings contribute to the literature, especially for marketing and Public Relations field of studies. Especially since research on consumer behaviour related to artificial sweetener products has not been widely studied involving its customers.

For practitioners, this research brings the message of the importance of establishing and maintaining corporate reputation. The company's reputation can affect brand image and brand loyalty. Unfortunately, in this case, the company's reputation has no direct effect on the buying intention. This event can happen if corporate branding activity is more focused on image development than to arouse customers' desire to make a purchase.

This study has several weaknesses. First, the participants were chosen by a purposive method. Although the selected buyers are buyers of the brand that are subjected to research and the spread of the questionnaire is done in several places, but because of nonprobability, the results of this study cannot be generalised to all customers of this brand and elsewhere. Second, in this current study, corporate reputation is an independent variable that influenced, directly and indirectly, other variables. For future research, the authors suggest to employ variables that might influence corporate reputation as documented by prior studies, such as word-of-mouth (Williams, Buttle, \& Biggemann, 2012), downsizing (Zyglidopoulos, 2004), corporate ability (Piriyakul \& Wingwon, 2013), corporate governance (Kumaran \& Thenmozhi, 2015), corporate social accountability (Behroozi, Meshkani, \& Rahmati, 2013), and corporate social responsibility (Mukasa, Lim, \& Kim, 2015). It is also possible to add other variables, such as brand trust and brand effect variables to 
predict brand loyalty (Suhud, Puteri, \& Wibowo, 2017).

\section{References}

1. Aaker, D. A. (2009). Managing brand equity: Simon and Schuster.

2. Alhaddad, A. (2014). The effect of brand image and brand loyalty on brand equity. International Journal of Business and Management Invention, 3(51), 28-32.

3. Ali, R., Lynch, R., Melewar, T., \& Jin, Z. (2015). The moderating influences on the relationship of corporate reputation with its antecedents and consequences: A meta-analytic review. Journal of Business Research, 68(5), 1105-1117.

4. Almeida, C., da Graça, M., \& Coelho, A. M. (2005). The impact of reputation in the performance of the organization in the perspective of members of the cooperatives. Business and Economics Journal, 8(4), 1-11. Retrieved from https://www.omicsonline.org/open-access/theimpact-of-corporate-reputation-in-a-dairycompany-2151-6219-1000320.pdf

5. Alwi, S. F. S., \& Kitchen, P. J. (2014). Projecting corporate brand image and behavioral response in business schools: Cognitive or affective brand attributes? Journal of Business Research, 67(11), 2324-2336.

6. Ambolau, M. A. P. (2015). The influence of brand awareness and brand image on purchase decision (Study on Aqua consumers in Administrative Science Faculty Brawijaya University Class of 2013). Jurnal Administrasi Bisnis, 19(2).

7. Awang, Z., \& Jusoff, K. (2009). The effects of corporate reputation on the competitiveness of Malaysian telecommunication service providers. International Journal of Business and Management, 4(5), 173.

8. Bandyopadhyay, S., \& Martell, M. (2007). Does attitudinal loyalty influence behavioral loyalty? A theoretical and empirical study. Journal of Retailing and Consumer services, 14(1), 35-44.

9. Behroozi, M., Meshkani, F. A., \& Rahmati, F. (2013). A study of the impact of corporate social responsbility on brand performance (Case study: Kaleh diary products industry,
Mazandaran Province, Iran). International Research Journal of Applied and Basic Sciences, 7(1), 6-14.

10.Bivainienè, L., \& Šliburytè, L. (2008). The brand image as an element of brand equity. Socialiniai Tyrimai (Social Research), 2(12), 2231.

11.Cecilia, M. (2014). Exploring the impact of brand equity, corporate reputation, and product quality on customer loyalty toward a national newspaper in Surabaya. iBuss Management, 2(2).

12.Cole, S. (2012). The impact of reputation on market value. World Economics, 13(3), 47-68.

13.Cretu, A. E., \& Brodie, R. J. (2007). The influence of brand image and company reputation where manufacturers market to small firms: A customer value perspective. Industrial Marketing Management, 36(2), 230240.

14.Das, G. (2014). Linkages of retailer awareness, retailer association, retailer perceived quality and retailer loyalty with purchase intention: A study of Indian food retail brands. Journal of Retailing and Consumer services, 21(3), 284-292.

15.de la Fuente, J. M., \& de Quevedo, E. (2003). The concept and measurement of corporate reputation: An application to Spanish financial intermediaries. Corporate Communications: $\mathrm{An}$ International Journal, 5(4), 280-230.

16.Dijkmans, C., Kerkhof, P., \& Beukeboom, C. J. (2015). A stage to engage: Social media use and corporate reputation. Tourism Management, 47, 58-67.

17.Espejel, J., Fandos, C., \& Flavian, C. (2008). Consumer satisfaction: A key factor of consumer loyalty and buying intention of a PDO food product. British Food Journal, 110(9), 865-881.

18.Fombrun, C. J., Ponzi, L. J., \& Newburry, W. (2015). Stakeholder tracking and analysis: The RepTrak® system for measuring corporate reputation. Corporate Reputation Review, 18(1), 3-24.

19.Gorondutse, A. H., Hilman, H., \& Nasidi, M. (2014). Relationship between corporate reputation and customer loyalty on Nigerian food and beverages industry: PLS approach. International Journal of Management and Business Research, 4(2), 125-136. 
20.Hair Jr., J. F., Black, W. C., Babin, B. J., Anderson, R. E., \& Tatham, R. L. (2006). Multivariate data analysis (6 ed.). New Jersey: Prentice-Hall, Inc.

21.Hoffmann, B. R., \& Greene, A. S. (2017). Mechanisms of vascular endothelial dysfunction: The problem with sugar and artificial sweeteners. The FASEB Journal, 31(1 Supplement), 853.859-853.859.

22.Hsu, K.-T. (2012). The advertising effects of corporate social responsibility on corporate reputation and brand equity: Evidence from the life insurance industry in Taiwan. Journal of Business Ethics, 109(2), 189-201.

23.Hu, L.-t., \& Bentler, P. M. (1995). Evaluating model fit. In R. H. Hoyle (Ed.), Structural equation modeling. Concepts, issues, and applications (pp. 76-99). London: Sage.

24.Hu, L.-t., \& Bentler, P. M. (1999). Cutoff criteria for fit indexes in covariance structure analysis: Conventional criteria versus new alternatives. Structural Equation Modeling: A Multidisciplinary Journal, 6(1), 1-55.

25.Hur, W.-M., Kim, H., \& Woo, J. (2014). How CSR leads to corporate brand equity: Mediating mechanisms of corporate brand credibility and reputation. Journal of Business Ethics, 125(1), 7586.

26.Jacoby, J., \& Kyner, D. B. (1973). Brand loyalty vs. repeat purchasing behavior. Journal of Marketing Research, 1-9.

27.Johan, M. R. M., \& Noor, A. Z. M. (2013). The role of corporate communication in building organization's corporate reputation: An exploratory analysis. Interdisciplinary Journal of Comtemporary Research in Business, 4(12), 1230-1240.

28.Khan, N., Rahmani, S. H. R., Hoe, H. Y., \& Chen, T. B. (2014). Causal relationships among dimensions of consumer-based brand equity and purchase intention: Fashion industry. International Journal of Business and Management, 10(1), 172.

29.Kumaran, V., \& Thenmozhi, R. (2015). Impact of corporate governance on corporate reputation. International Journal of Management and Commerce Innovations, 3(2), 1-8.
30.Liengjindathaworn, S., Saenchaiyathon, K., \& Hawat, P. (2015). Effect of corporate reputation to brand loyalty of banks in Thailand. International Business Management, 9(1), 134138.

31.Lin, H., Wu, J., Oturan, N., Zhang, H., \& Oturan, M. A. (2016). Degradation of artificial sweetener saccharin in aqueous medium by electrochemically generated hydroxyl radicals. Environmental Science and Pollution Research, 23(5), 4442-4453.

32.Mohammad, A. A. S. (2017). The impact of brand experiences, brand equity and corporate branding on brand loyalty: Evidence from Jordan. International Journal of Academic Research in Accounting, Finance and Management Sciences, 7(3), 58-69.

33.Momani, R. A. (2015). The Impact of brand dimension on the purchasing decision making of the Jordanian onsumer for shopping goods. 6(7), 149-168. Retrieved from http://ijbssnet.com/journals/Vol 6 No 7 July 2 015/17.pdf

34.Mukasa, K. D., Lim, H., \& Kim, K. (2015). How do corporate social responsibility activities influence corporate reputation? Evidence from Korean firms. Journal of Applied Business Research, 31(2), 383.

35.Patel, J., Domingues, C., Kundu, N., Ahmadi, N., Sylvetsky, A. C., Rother, K., \& Sen, S. (2017, Spring 2017). Artificial sweetener such as sucralose may promote inflammation in human subcutaneous fat-derived Mesenchymal Stromal Cells (MSCs). Retrieved from https://hsrc.himmelfarb.gwu.edu/gw research days/2017/SMHS/68/

36.Petzer, D., Mostert, P., Kruger, L.-M., \& Kuhn, S. (2014). The dimensions of brand romance as predictors of brand loyalty among cell phone users. South African Journal of Economic and Management Sciences, 17(4), 457-470.

37.Piriyakul, M., \& Wingwon, B. (2013). Effect of corporate ability and reputation on organizations' performance and CSR. African Journal of Business Management, 7(9), 738.

38.Prabowo, A. (2013). Analysing the impact of product quality, brand trust, brand image, and customer satisfaction on brand loyalty of a mineral water product (in Bahasa Indonesia). (Bachelor), Universitas Islam Negeri Syarif Hidayatullah Jakarta. 
39.Pratoom, K. (2010). Validating the reputation quotient scale: Human resource management perspective. International Business Management, 4(4), 243-249.

40.Saleem, H., \& Raja, N. S. (2014). The impact of service quality on customer satisfaction, customer loyalty and brand image: Evidence from hotel industry of Pakistan. Middle-East Journal of Scientific Research, 19(5), 706-711.

41.Schermelleh-Engel, K., Moosbrugger, H., \& Müller, H. (2003). Evaluating the fit of structural equation models: Tests of significance and descriptive goodness-of-fit measures. Methods of Psychological Research Online, 8(2), 23-74.

42.Schwaiger, M. (2004). Components and parameters of corporate reputation- An empirical study. Schmalenbach business review, $56,46-71$

43.Seo, E.-J., \& Park, J.-W. (2016). A study on the impact of airline corporate reputation on brand loyalty. International Business Research, 10(1), 59.

44.Shukla, P. (2009). Impact of contextual factors, brand loyalty and brand switching on purchase decisions. Journal of Consumer Marketing, 26(5), 348-357.

45.Suhud, U. (2014). A moment to give, no moment to take: A mixed-methods study on volunteer tourism marketing: Lap Lambert Academic Publishing.

46.Suhud, U., Puteri, C. D., \& Wibowo, S. F. (2017). Measuring brand loyalty of coffee shop visitors in Jakarta. ASEAN Marketing Journal, IX(1), 28-39. Retrieved from http://journal.ui.ac.id/index.php/amj/article/vi ew/8902/4072

47.Susilawati, D., \& Rezkisari, I. (2015). Indonesia occupy ranked fifth most diabetes patients (in Bahasa Indonesia). Retrieved from Reublika.go.id website: http://www.republika.co.id/berita/gayahidup/info-sehat/15/08/21/ntejc5328indonesia-duduki-peringkat-kelima-penderitadiabetes-terbanyak Retrieved from http://www.republika.co.id/berita/gayahidup/info-sehat/15/08/21/ntejc5328indonesia-duduki-peringkat-kelima-penderitadiabetes-terbanyak

48.Tabachnick, B. G., \& Fidell, L. S. (2007). Using multivariate statistics (5 ed.). Boston Pearson/Allyn \& Bacon.

49.Vahabzadeh, A., Vatanpour, H., Dinarvand, R., Rajabzadeh, A., Salamzadeh, J., \& Mohammadzadeh, M. (2017). Impact of corporate reputation on brand differentiation an empirical study from Iranian pharmaceutical companies. Iranian Journal of Pharmaceutical Research, 16(4).

50.Widowati, U. (2015). 10 most deadly disease in Indonesia (in Bahasa Indonesia). Retrieved from CNNIndonesia.com website: http://www.cnnindonesia.com/gayahidup/20150513163407-255-53129/10penyakit-paling-mematikan-di-indonesia/ Retrieved from http://www.cnnindonesia.com/gayahidup/20150513163407-255-53129/10penyakit-paling-mematikan-di-indonesia/

51.Williams, M., Buttle, F., \& Biggemann, S. (2012). Relating word-of-mouth to corporate reputation. Public Communication Review, 2(2).

52.Zhang, H., Fu, X., Cai, L. A., \& Lu, L. (2014). Destination image and tourist loyalty: A metaanalysis. Tourism Management, 40, 213-223.

53.Zyglidopoulos, S. C. (2004). The impact of downsizing on the corporate reputation for social performance. Journal of Public Affairs, $4(1), 11-25$. 